\title{
A proposal for a new Brazilian six-item version of the Edinburgh Postnatal Depression Scale
}

\author{
Proposta para uma nova versão brasileira de seis itens da Escala de Depressão \\ Pós-Parto de Edimburgo
}

\begin{abstract}
Maicon Rodrigues Albuquerque, ${ }^{1,2}$ Humberto Corrêa, 2,3,4 Tiago Castro e Couto, ${ }^{3}$ Wallace Santos, ${ }^{5}$ Marco Aurelio Romano-Silva, 2,3,4 Leonor Maria Pacheco Santos ${ }^{5,6}$
\end{abstract}

\begin{abstract}
Introduction: Factor analysis of the Edinburgh Postnatal Depression Scale (EPDS) could result in a shorter and easier to handle screening tool. Therefore, the aim of this study was to check and compare the metrics of two different 6-item EPDS subscales.

Methods: We administered the EPDS to a total of 3,891 women who had given birth between 1 and 3 months previously. We conducted confirmatory and exploratory factor analyses and plotted receiver-operating characteristics (ROC) curves to, respectively, determine construct validity, scale items' fit to the data, and ideal cutoff scores for the short versions.

Results: A previously defined 6-item scale did not exhibit construct validity for our sample. Nevertheless, we used exploratory factor analysis to derive a new 6-item scale with very good construct validity. The area under the ROC curve of the new 6 -item scale was 0.986 and the ideal cutoff score was $\geq 6$. Conclusions: The new 6-item scale has adequate psychometric properties and similar ROC curve values to the 10 -item version and offers a means of reducing the cost and time taken to administer the instrument.
\end{abstract}

Keywords: Postpartum depression, affective symptoms, EPDS.

\section{Introduction}

The Edinburgh Postnatal Depression Scale (EPDS) is a 10 -item scale developed in the 1980 s by Cox et al. as

\section{Resumo}

Introdução: A análise fatorial da Escala de Depressão Pós-Parto de Edimburgo (Edinburgh Postnatal Depression Scale, EPDS) poderia resultar em uma ferramenta de triagem mais curta e mais fácil de aplicar. Portanto, o objetivo deste estudo foi verificar e comparar as métricas de duas subescalas EPDS de 6 itens.

Métodos: Administramos a EPDS a um total de 3.891 mulheres que deram à luz entre 1 e 3 meses antes da aplicação. Foram realizadas análises fatoriais confirmatórias e exploratórias e geradas curvas ROC (receiver-operating characteristics) para determinar, respectivamente, a validade do construto, o ajuste dos itens da escala aos dados, e os pontos de corte ideais para as versões curtas. Resultados: A escala de 6 itens previamente publicada não apresentou validade de construto para nossa amostra. No entanto, utilizamos a análise fatorial exploratória para derivar uma nova escala de 6 itens, que apresentou boa validade de construto. A área sob a curva ROC da nova escala de 6 itens foi 0,986, e o ponto de corte ideal foi $\geq 6$.

Conclusão: A nova escala de 6 itens possui propriedades psicométricas adequadas e valores de curva ROC semelhantes à versão de 10 itens e oferece um meio de reduzir o custo e o tempo necessário para administrar o instrumento.

Descritores: Depressão pós-parto, sintomas afetivos, EPDS.

\footnotetext{
${ }^{1}$ Departamento de Esportes, Universidade Federal de Minas Gerais (UFMG), Belo Horizonte, MG, Brazil. ${ }^{2}$ Instituto Nacional de Ciência e Tecnologia em Medicina Molecular (INCT-MM), UFMG, Belo Horizonte, MG, Brazil. ${ }^{3}$ Programa de Pós-Graduação em Medicina Molecular, Faculdade de Medicina, UFMG, Belo Horizonte, MG, Brazil. ${ }^{4}$ Departamento de Saúde Mental, Faculdade de Medicina, UFMG, Belo Horizonte, MG, Brazil. ${ }^{5}$ Programa de Pós-Graduação em Saúde Coletiva, Universidade de Brasília (UnB), Brasília, DF, Brazil. ${ }^{6}$ Departamento de Saúde Coletiva, Universidade de Brasília (UnB), Brasília, DF, Brazil. Financial support: none.

Submitted Jul 28 2016, accepted for publication Nov 04 2016. No conflicts of interest declared concerning the publication of this article.

Suggested citation: Albuquerque MR, Corrêa H, Castro e Couto T, Santos W, Romano-Silva MA, Santos LM. A proposal for a new Brazilian six-item version of the Edinburgh Postnatal Depression Scale. Trends Psychiatry Psychother. 2017;39(1):29-33. http://dx.doi.org/10.1590/2237-6089-2016-0056
} 
only for postpartum but also for antenatal depression. ${ }^{2,3}$ Furthermore, Matijasevich et al. ${ }^{4}$ proposed and validated its use in the general population.

Notwithstanding, there is a debate on the use of EPDS for PPD screening in public health systems because it can result in a false-positive rate of approximately $25 \%$, which means it is not cost-effective. ${ }^{5}$ This has motivated studies of the EPDS' factor structure and prompted the suggestion that a shorter EPDS depression subscale could provide a better predictive scale for depression than the entire EPDS. ${ }^{6}$ From a public health perspective, this could reduce costs by avoiding unnecessary referrals to psychiatrists for a screening tool. Moreover, a shorter version demands less time for administration and would be more easily remembered, allowing more widespread use for detection of patients suffering from PPD.7

We recently studied the psychometric characteristics of the EPDS in a Brazilian sample of 245 women in order to assess its utility as a screening tool for PPD in the Brazilian public health system. ${ }^{8}$ After performing exploratory factor analysis (EFA) on the original 10-item EPDS scale, two different subscales (anxiety and depression) were obtained and a 6-item version was derived that had similar psychometric proprieties, at least for that sample. ${ }^{9}$

The aim of the present study was to test the psychometric properties of that 6-item version of the EPDS, proposed by Malloy-Diniz et al., 9 in a larger sample comprising 3,891 women with very different socio-demographic characteristics (from Amazonian and Northeastern Brazil). Furthermore, we also used a more robust statistical approach, since EFA conducted using SPSS may not produce an adequate assessment of model fit, which is better achieved by conducting several statistical tests to determine how well the model fits the data. ${ }^{10,11}$

\section{Methods}

\section{Procedures}

A cross-sectional study (the Neonatal Survey: assessment of prenatal and neonatal health care in the North and Northeast of Brazil) was carried out in June 2010, during the first round of the National Immunization Day, in 252 towns located in 17 states in the Amazon and Northeast regions that had signed up to the Ministry of Health's "Pact to Reduce Infant and Maternal Mortality." A population of 16,863 Brazilian public health system users, all mothers of children under 1 year old, was interviewed in order to assess socio-demographic variables and the quality of their prenatal, delivery, and postpartum care and of the health care provided to their children.
The survey interviewed all women who had given birth between 1 and 3 months previously and presented with postpartum depression symptoms ( $n=3,891) .^{12}$ Trained personnel administered the EPDS to these mothers, reading each question and its response options aloud in a private setting in primary health care centers, because respondents in the regions studied were poorly educated. Administration of the EPDS as an interview is accepted by the instrument's authors. ${ }^{1}$ All mothers signed informed consent forms authorizing their participation in the research.

The Neonatal Survey was approved by the Research Ethics Committee of the National School of Public Health at Fundação Oswaldo Cruz (Rio de Janeiro, Brazil), identification number 56/10. Mothers who screened positive for PPD were referred for psychiatric care in psychosocial health centers.

\section{Data analysis}

The construct validity of the 10 and 6-item EPDS were evaluated by conducting confirmatory factor analysis (CFA) on their items, while EFA with the weighted least squares estimation method (WLSM) was conducted to fit the scale items. The WLSM estimator was used because this estimator is recommended as a good alternative when the data are non-normal because of a scale's ordinal nature (e.g., a Likert-type scale of less than seven points), ${ }^{13}$ as is the case of the EPDS. Additionally, we also used a ReceiverOperating Characteristics (ROC) curve to define a cutoff for the new short version, using the 10-item version's cutoff.

As suggested by Kline11 and Brown, ${ }^{10}$ root mean square error of approximation (RMSEA), comparative fit index (CFI), the standardized root mean square residual (SRMR), and the Tucker-Lewis index (TLI) were used to evaluate the model's fit. A cutoff criterion of greater than or equal to 0.90 is recommended for the CFI and TLI. Additionally, RMSEA and SRMR values below 0.08 are considered acceptable. ${ }^{10,11}$

Cronbach's alpha was calculated to assess internal consistency, using SPSS version 20. Mplus, version 6.12, was used for CFA and EFA. MedCalc version 12.5 was used for ROC curve analysis.

\section{Results}

\section{Sample characteristics}

Most mothers were at least 20 years old, non-white, had high school education, were in the second month postpartum, and did not have low-birth-weight babies 
(Table 1). Most of them were not beneficiaries of the "Bolsa Família", the Brazilian conditional cash transfer program (probably because they were not extremely poor), and rated their prenatal and childbirth care as good (data not shown).

Table 1 - Characteristics of anxiety and control groups

\begin{tabular}{lc}
\hline Variables & $\mathbf{n ~ ( \% )}$ \\
\hline Total & 3,891 \\
Place of residence & \\
$\quad$ Capital city & $1,992(51.2)$ \\
Interior & $1,899(48.8)$ \\
Age & \\
$<20$ & $825(21.5)$ \\
$\geq 20$ & $3,015(78.5)$ \\
Skin color/ethnicity & \\
Black and others & $3,092(79.8)$ \\
White & $783(20.2)$ \\
Education (years) & \\
$\leq 7$ & $1,045(27.1)$ \\
$8-10$ & $1,150(29.9)$ \\
$\geq 11$ & $1,655(43.0)$ \\
Postpartum (month) & \\
1st & $1,031(26.5)$ \\
2nd & $1,506(38.7)$ \\
3rd & $1,354(34.8)$ \\
Child's sex & \\
Male & $1,989(51.1)$ \\
Female & $1,902(48.9)$ \\
Cesarean section birth & \\
No & $1,894(50.3)$ \\
Yes & $1,872(49.7)$ \\
Low birth weight child & \\
No & $3.590(94.2)$ \\
Yes & $221(5.8)$ \\
\hline
\end{tabular}

\section{Edinburgh Postnatal Depression Scale (EPDS) analysis}

The CFA of the 6-item EPDS proposed previously (8) was conducted with a 1 -factor structure. The fit indices were $\mathrm{x}^{2}(9)=407.315 ; \mathrm{p}<0.001 ; \mathrm{CFI}=0.80$; TLI $=$ 0.67, RMSEA $=0.107 ;$ SRMR $=0.057$. Therefore, the fit indices for the 6-item EPDS (Table 2) proposed by Malloy-Diniz et al. ${ }^{9}$ were not acceptable. For this reason, EFA was conducted using the original (10-item) version.

Based on the six highest factor loadings (Table $2)$, four items were excluded in the next analysis producing a new 6-item EPDS scale (Figure 1), for which fit indices were excellent $\left(X^{2}(9)=194.74 ; p<\right.$ $0.001 ;$ CFI $=0.97$, TLI $=0.95$, RMSEA $=0.073$; SRMR $=0.030)$.
Table 2 - Summary of three Portuguese Versions of the Edinburgh Postpartum Depression Scale

\begin{tabular}{|c|c|c|c|}
\hline Items & 10-item & 6-item ${ }^{9}$ & New 6-Item \\
\hline $\begin{array}{l}\text { 1. Eu tenho sido capaz } \\
\text { de rir e achar graça das } \\
\text { coisas }\end{array}$ & $x$ & $x$ & \\
\hline $\begin{array}{l}\text { 2. Eu sinto prazer quando } \\
\text { penso no que está por } \\
\text { acontecer em meu dia- } \\
\text { a-dia }\end{array}$ & $x$ & $x$ & \\
\hline $\begin{array}{l}\text { 3. Eu tenho me sentido } \\
\text { culpada sem necessidade } \\
\text { quando as coisas saem } \\
\text { erradas }\end{array}$ & $x$ & $x$ & \\
\hline $\begin{array}{l}\text { 4. Eu tenho me sentido } \\
\text { ansiosa ou preocupada } \\
\text { sem uma boa razão }\end{array}$ & $x$ & $x$ & $x$ \\
\hline $\begin{array}{l}\text { 5. Eu tenho me sentido } \\
\text { assustada ou em pânico } \\
\text { sem um bom motivo }\end{array}$ & $x$ & $x$ & $x$ \\
\hline $\begin{array}{l}\text { 6. Eu tenho me sentido } \\
\text { esmagada pelas tarefas e } \\
\text { acontecimentos do meu } \\
\text { dia-a-dia }\end{array}$ & $x$ & & \\
\hline $\begin{array}{l}\text { 7. Eu tenho me sentido } \\
\text { tão infeliz que tenho tido } \\
\text { dificuldade de dormir }\end{array}$ & $x$ & $x$ & $x$ \\
\hline $\begin{array}{l}\text { 8. Eu tenho me sentido } \\
\text { triste ou arrasada }\end{array}$ & $x$ & & $x$ \\
\hline $\begin{array}{l}\text { 9. Eu tenho me sentido } \\
\text { tão infeliz que tenho } \\
\text { chorado }\end{array}$ & $x$ & & $x$ \\
\hline $\begin{array}{l}\text { 10. A ideia de fazer mal a } \\
\text { mim mesma passou por } \\
\text { minha cabeça }\end{array}$ & $x$ & & $x$ \\
\hline
\end{tabular}

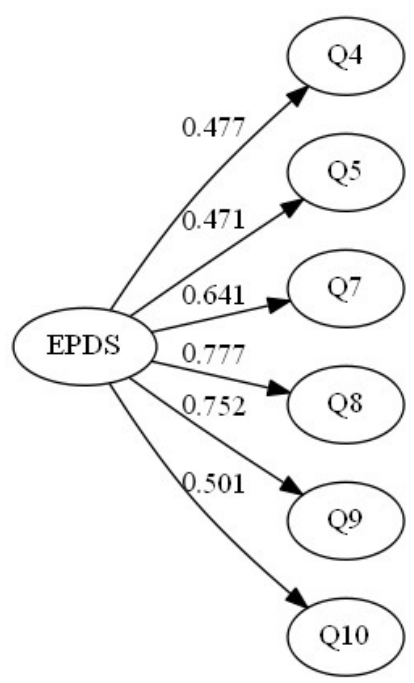

Figure 1 - Fit indices for exploratory factor analysis with factor loadings of the new 6-item Edinburgh Postnatal Depression Scale (EPDS).

Cronbach's alphas for the 10-item and the previous 6 -item scales were 0.79 and 0.66 respectively. The new 6 -item scale had a Cronbach's alpha of 0.78. 
Figure 2 illustrates the ROC curve analysis. The area under the curve for the new 6-item scale was 0.986 (95\% confidence interval: $0.982-0.990, \mathrm{p}<0.001$ ), which can be considered excellent. A cutoff of " $>6$ " offered the best compromise between sensitivity $(92.7 \%)$ and specificity (95.8\%).

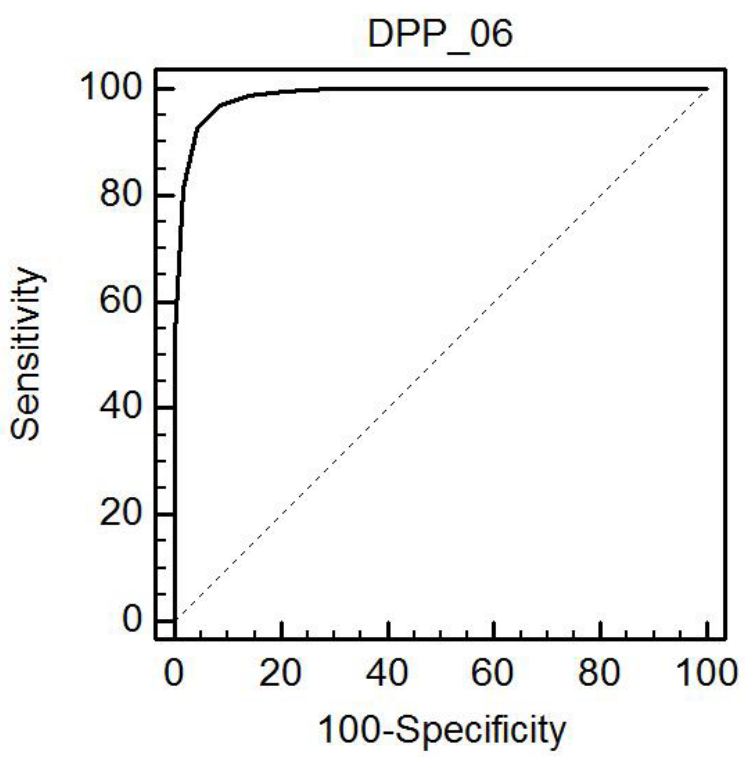

Figure 2 - Receiver-operating characteristics (ROC) curve for determination of the ideal cutoff for the new 6-item scale.

\section{Discussion}

The EPDS was originally described as a 10-item one-dimensional measure of postpartum depression. ${ }^{1}$ Recently, we proposed a shorter 6-item version with good psychometric properties. The present paper re-assessed the psychometric properties of the 6-item version EPDS proposed by Malloy-Diniz et al., ${ }^{9}$ using a more robust statistical approach and a larger population sample.

It has been suggested that the EPDS could be viewed more as a psychological distress instrument than a onedimensional measure of postpartum depression. ${ }^{14}$ In fact, we have previously found that EPDS could have two dimensions (anxiety and depression), ${ }^{9}$ whereas others have even found three-dimensional factor structures (depression, anxiety and suicide ${ }^{6,15}$ or depression, anxiety and anhedonia). ${ }^{16}$ Furthermore, some studies have shown that other shorter EPDS versions, including a 7-item version and even a 2-item version, are also highly accurate for assessment of depression. ${ }^{7}$
After performing CFA, we found that the fit indices for the 6-item Malloy-Diniz et al. version ${ }^{9}$ indicated unacceptable model fit. Therefore, after conducting EFA for the original EPDS version (10-item), we derived a new 6 -item version. Our results demonstrated that this new 6-item version exhibited acceptable psychometric properties. Additionally, the ROC curve showed that, compared to the 10-item version, our new 6-item version exhibit a similar capacity (sensitivity $=92.7 \%$, and specificity $=95.8 \%$ ) for discriminating between patients with and without postpartum depression.

A practical definition of an instrument's reliability is its ability to provide consistent measures and this is closely related to its validity. ${ }^{17}$ In the present study we used Cronbach's alpha to measure reliability. Notwithstanding, this measure has received some criticism. ${ }^{18}$ Despite understanding the limitations of Cronbach's alpha, ${ }^{18}$ and being aware that other methods could have been used, ${ }^{19}$ we nevertheless decided to use Cronbach's alpha because it is probably the most widely-used reliability measure in scale validation studies and was also the measure employed in the tests described by Malloy-Diniz et al. ${ }^{9}$ Our results showed that the new 6 -item version had acceptable internal consistency ( $a=0.78$ ), as did both the original 10 -item version $(a=0.79$ ) and the Malloy-Diniz et al. ${ }^{9} 6$-item version $(a=0.66)$.

Our new 6-item version exhibited adequate psychometric properties, with almost the same values for sensitivity and specificity as the 10 -item version. Nevertheless, it is important to emphasize that the 10item version has proved prone to an elevated falsepositive rate $(\cong 25 \%),{ }^{5}$ which could also be a limitation of our new 6 -item version. However, we argue that a shorter scale reduces application time and costs and should therefore help to address the current situation of under diagnosis, which is mainly observed in undeveloped countries where health services may not be structured. In other words, a shorter, reliable scale could be the difference between screening for PPD or not in some settings.

The prevalence of PPD is high worldwide and it is even higher in undeveloped countries. ${ }^{12}$ Considering that screening and treatment of PPD improve outcomes, ${ }^{20,21}$ that perinatal depression can have significant effects on the child's cognitive, emotional and social development, ${ }^{22}$ and that these children may be even more vulnerable in undeveloped countries; using a shorter scale may be a crucial issue.

An important strength of our study is the large population studied (3,891 women from Amazonian and Northeastern Brazil, both rural and urban areas) which is representative of the population where this tool could be used in public health screening. A limitation of our study 
is that in the present sample it was not possible to use the gold standard Mini Plus-5.0 or SCID for diagnosis of postpartum depression, which could have provided more robust data.

In conclusion, our new 6-item scale has adequate psychometric properties and exhibited high values under the ROC curve and could be a way to reduce the time taken to administrate the instrument, possibly resulting in reduced costs and also lower rates of misdiagnosis and under diagnosis.

\section{References}

1. Cox JL, Holden JM, Sagovsky R. Detection of postnatal depression. Development of the 10-item Edinburgh Postnatal Depression Scale. Br J Psychiatry. 1987;150:782-6.

2. Gibson J, McKenzie-McHarg K, Shakespeare J, Price J, Gray R. A systematic review of studies validating the Edinburgh Postnatal Depression Scale in antepartum and postpartum women. Acta Psychiatr Scand. 2009;119:350-64.

3. Castro E Couto T, Martins Brancaglion MY, Nogueira Cardoso M, Bergo Protzner A, Duarte Garcia F, Nicolato R, et al. What is the best tool for screening antenatal depression? J Affect Disord. 2015;178:12-7.

4. Matijasevich A, Munhoz TN, Tavares BF, Barbosa AP, da Silva DM, Abitante MS, et al. Validation of the Edinburgh Postnatal Depression Scale (EPDS) for screening of major depressive episode among adults from the general population. BMC Psychiatry. 2014;14:284.

5. Paulden M, Palmer S, Hewitt C, Gilbody S. Screening for postnatal depression in primary care: cost effectiveness analysis. BMJ. 2009;339:b5203.

6. Phillips J, Charles M, Sharpe L, Matthey S. Validation of the subscales of the Edinburgh Postnatal Depression Scale in a sample of women with unsettled infants. J Affect Disord. 2009;118:10112.

7. Venkatesh KK, Zlotnick C, Triche EW, Ware C, Phipps MG. Accuracy of brief screening tools for identifying postpartum depression among adolescent mothers. Pediatrics. 2014;133:e45-53.

8. Figueira $P$, Corrêa $H$, Malloy-Diniz L, Romano-Silva MA. Edinburgh Postnatal Depression Scale for screening in the public health system. Rev Saude Publica. 2009;43:79-84

9. Malloy-Diniz LF, Schlottfeldt CGMF, Figueira P, Neves FS, Corrêa $\mathrm{H}$. [Edimburg Postpartum Depression Scale: factorial analyses and development of six items versio]. Rev Bras Psiquiatr. 2010;32:316-
8.

10. Brown TA. Confirmatory factor analysis for applied research. New York: Guilford; 2006.

11. Kline RB. Principles and practice of structural equation modeling. 3th ed. New York: Guilford; 2011.

12. Correa H, Castro E Couto T, Santos W, Romano-Silva MA, Santos LM. Postpartum depression symptoms among Amazonian and Northeast Brazilian women. J Affect Disord. 2016;204:214-8.

13. Chen PY, Yang CM, Morin CM. Validating the cross-cultural factor structure and invariance property of the Insomnia Severity Index: evidence based on ordinal EFA and CFA. Sleep Med. 2015;16:598603.

14. Montazeri A, Torkan B, Omidvari S. The Edinburgh Postnatal Depression Scale (EPDS): translation and validation study of the Iranian version. BMC Psychiatry. 2007;7:11.

15. Jomeen J, Martin CR. Replicability and stability of the multidimensional model of the Edinburgh Postnatal Depression Scale in late pregnancy. J Psychiatr Ment Health Nurs. 2007;14:31924.

16. Chabrol H, Teissedre F. Relation between Edinburgh Postnata Depression Scale scores at 2-3 days and 4-6 weeks postpartum. J Reprod Infant Psychol. 2004;22:33-9.

17. Tavakol M, Dennick R. Making sense of Cronbach's alpha. Int J Med Educ. 2011;2:53-5.

18. Sijtsma K. On the use, the misuse, and the very limited usefulness of Cronbach's alpha. Psychometrika. 2009;74:107-20.

19. Hopkins WG. Measures of reliability in sports medicine and science. Sports Med. 2000;30:1-15.

20. Fitelson E, Kim S, Baker AS, Leight K. Treatment of postpartum depression: clinical, psychological and pharmacological options. Int J Womens Health. 2010;3:1-14.

21. Sockol LE. A systematic review of the efficacy of cognitive behavioral therapy for treating and preventing perinatal depression. J Affect Disord. 2015;177:7-21.

22. Stein A, Pearson RM, Goodman SH, Rapa E, Rahman A, McCallum $M$, et al. Effects of perinatal mental disorders on the fetus and child. Lancet. 2014;384:1800-19.

\section{Correspondence:}

Maicon Rodrigues Albuquerque

Departamento de Esportes, Escola de Educação Física, Fisioterapia e Terapia Ocupacional (EEFFTO), Universidade Federal de Minas Gerais (UFMG)

Av. Presidente Carlos Luz, 6627 - Pampulha

31270-901 - Belo Horizonte, MG - Brazil

Tel./Fax: +55 (31) 3409-2331

E-mail: lin.maicon@gmail.com 